\title{
A STUDY ON THE CHEMICAL AND MINERAL COMPOSITION OF THE PROTEIN-MINERAL PASTE FROM POULTRY AND CATTLE BONE RAW MATERIALS
}

\author{
Aitbek K. Kakimov ${ }^{1}$, Zhanibek S. Yessimbekov ${ }^{1 *}$, Baktybala K. Kabdylzhar', \\ Anuarbek K. Suychinov ${ }^{2}$, Assemgul M. Baikadamova \\ ${ }^{1}$ Shakarim University, Semey, Kazakhstan \\ ${ }^{2}$ Kazakh Research Institute of Processing and Food Industry (Semey Brunch), Semey, Kazakhstan
}

\begin{abstract}
Keywords: meat-bone paste, fine grinding, chemical composition, slaughtered cattle bones, poultry bones
\section{Abstract}

When processing cattle and poultry, a large quantity of secondary slaughter products in the form of bone raw materials are formed in enterprises of the meat and poultry processing industry. Nowadays, its use is not optimal and rational. One of the promising directions of using bone raw materials in enterprises is production of finely ground meat and bone paste. The aim of this research was to study the chemical and mineral compositions, as well as the content of toxic elements in meat and bone paste from poultry and cattle bones obtained after complex grinding on a grinder and ultra-fine grinder. Chicken bone products (chicken necks, drumsticks, wings, breasts) and cattle costal and vertebral bones with residues of muscle tissue were used for investigation. The comparative analysis of the nutritional value of the meat and bone paste showed the following results: protein mass fraction was $18.5 \%$ in the meat and bone paste obtained from poultry bones, and $12.1 \%$ in the meat and bone paste obtained from cattle bones. The mass fraction of fat was two times higher in the meat and bone paste from poultry bones. As for the mineral composition, it has been established that meat and bone paste is a rich source of calcium: the calcium content was 1,654.02 mg/100 in the poultry meat and bone paste, and 5,318.13 $\mathrm{mg} / 100 \mathrm{~g}$ in the cattle meat and bone paste. In regard to the toxic element content, the normed values of lead and arsenic, cadmium and mercury were not revealed in the poultry and cattle meat and bone paste. The obtained meat and bone paste can be used for food purposes as a food additive in meat product manufacture, which will allow rational and economic use of bone raw materials in cattle and poultry processing.
\end{abstract}

\section{Introduction}

Nowadays, most meat processing enterprises face an acute problem of the maximum and rational use of secondary products of processing farm animals and poultry. When processing initial raw materials, valuable kinds of secondary raw material resources are obtained, such as blood, bone, by-products of the 2 nd category, crude fat, nonedible by-products and others. They can be used for manufacturing additional food, feed and technical products $[1,2]$. Wider introduction of complex processing of secondary raw materials will enable its rational use as the main components in the meat product technology increasing product output and assortment [3].

A carcass or half-carcass obtained by slaughter of farm animals and poultry is a complex of muscle, fatty, connective and bone tissues. The rational use of bones from slaughter animals and implementation of non-waste and low-waste technological processes into production has assumed great importance allowing exclusion or minimization of losses and assurance of high-quality products. Moreover, bone raw materials is a source of mineral, protein and fat substances $[4,5]$.

In the Republic of Kazakhstan and CIS states, there are few technologies for processing cattle and poultry meat and bone raw materials to the state of finely ground paste.
In the foreign countries, meat and bone paste production is common in Japan and China $[6,7,8,9]$.

At present, there are many technological solutions for bone raw material processing that differ from each other by technological parameters, equipment, process duration and so on. Their common feature is striving for maximum extraction of edible components, edible and technical fat, collagen, mineral substances (components) from raw materials by the mechanical, physical, chemical and thermal impact on bones [10].

L. V. Antipova et al. [11] studied the poultry bone residue regarding the nutritional value and proposed a recipe and technology for dry concentrate production based on broth from poultry bone residue. The authors noted that in terms of the chemical composition, the bone residue contained $25 \%$ of protein, $18.9 \%$ of fat and $11.1 \%$ of ash. In regard to the mineral composition, the high content of calcium (3900 mg/kg), phosphorus (2000 mg/kg) and iron (101.8 mg/kg) was observed.

Meat and bone raw materials are used for food purposes as protein hydrolysates and mineral additives, bone broth and fat are produced after corresponding technological processing. For example, an effective and cost efficient technology for processing poultry meat and bone raw materials was created [12]. By hydrolysis of chicken necks in 
the presence of an inorganic catalyzer, a protein product was obtained, which can be used in sausage production, in production of minced semi-finished products, meat fillings and delicacies. Addition of the protein mixture enables increasing the nutritional value and yield of finished delicacy products, improving their sensory properties and rheological characteristics.

Kutsakova et al. [13] developed technologies of threestage hydrolysis of meat and bone residue of broiler chickens and carcasses of laying hens that allow obtaining foodgrade protein hydrolysates that differ by composition and functional-technological properties. Recommendations on the use of hydrolysates as protein additives in meat product manufacture were developed.

The study [14] was devoted to investigation of bone raw material hydrolysis and production of hydrolysates using bone waste from meat, poultry and fish with food additive production. As a result of the hydrolysis of protein mixture from meat and bone raw materials and blood with enzymes of the activated yeast biomass and pancreas, the hydrolysate with the amino acid composition close to optimal was obtained.

Mezenova et al. [15] developed and determined modification parameters for meat and bone raw materials by the hydrolytic method under an action of high temperatures $\left(140{ }^{\circ} \mathrm{C}\right)$ and increased pressure in the aqueous medium $(0.62 \mathrm{MPa})$ to remove valuable protein, fatty and mineral substances. The method of high-temperature modification of meat and bone raw materials allows the complex use of all organic components of raw materials (proteins, minerals, fatty acids) while preserving their native nature and ensuring their sanitary safety. Products of modification of meat and bone raw materials are recommended for the use as food and feed additives, in the composition of biologically active food additives with the osteotropic and gerodietetic direction, microbiological media, feeds for aquaculture, fatty compositions.

Wang et al. [16] used the method of hot-pressure extraction (HPE) for extraction of nutrients (protein, collagen, and minerals) from chicken bone residues. High ratios of protein $(83.51 \%)$ and collagen $(96.81 \%)$ were obtained at $135{ }^{\circ} \mathrm{C}$ and $120 \mathrm{~min}$. Essential amino acids accounted for $31.03 \%$ to $47.73 \%$ of total amino acids in the extract of chicken bones. However, the calcium content in the extract of chicken bones ( 4.2 to $4.8 \mathrm{mg} / 100 \mathrm{~g}$ ) was relatively low compared to that in the chicken bone residue $(1078 \mathrm{mg} / 100 \mathrm{~g})$. Extracts of chicken bones were obtained by heating at $130 \pm 0.5^{\circ} \mathrm{C}$ for $120 \mathrm{~min}$. with following filtration, sedimentation, defatting and concentration. Extracts contain ideal protein and fat, which makes them an excellent substrate for hydrolysis. Extract hydrolysates are potentially suitable food additives in the food industry [17]. It can be concluded that hot-pressure extraction is a method for transformation of chicken bone residues into a nutritional substrate with a flavoring agent; however, it is not an effective way for calcium extraction.
Zhang et al. [18] obtained collagen from chicken bone. Fat, minerals and hybrid protein were removed using ethyl acetate, hydrochloric acid and calcium hydroxide, respectively. The optimal process of collagen extraction envisaged the solid-liquid ratio 1: 8, extraction temperature $100{ }^{\circ} \mathrm{C}$, extraction time $4 \mathrm{~h}$ and $\mathrm{pH} 4.0$. The content of extracted protein was $88.75 \%$, collagen $86.02 \%$. An ultra-fine bone powder was prepared from bone residues using an ultra-fine pulverizer. Then, the content of nutrients was determined. This method not only solves the environmental problems of livestock and poultry processing industry but also opens new channels and new areas for studying functional foods, and has good social and economic benefits.

Another direction of using bone raw materials is collagen production. Cansu et al. [19] developed a multi-step procedure for collagen isolation from chicken bones that allowed removing $87.5 \%$ of minerals and $57.1 \%$ of fats with protein losses of about $18.6 \%$ and hydroxyproline losses of $14.9 \%$. The collagen yield was about $85 \%$ of the initial content, its quality and functional properties were assessed.

Suparno et al. [20] and Kodous et al. [21] described isolation of collagen from chicken feet in the acetic acid solution at $4{ }^{\circ} \mathrm{C}$ for 24 hours using papain and pepsin with the yield of $18.16 \%$ and $22.94 \%$. The obtained collagen contained large amounts of glycine, glutamic acid, proline and hydroxiproline.

These methods of bone raw material processing are based on thermal, acid treatment, which main disadvantage is the loss of nutrients. Moreover, there are significant energy expenditures and labor intensity in several processes.

In this connection, it is necessary to emphasize particularly such direction in bone processing for food purposes as its processing into the finely dispersed mass for using in production of different meat product types. Processing of meat and bone raw materials into finely dispersed paste allows adding this product into sausages, meat semifinished products such as pelmeni, cutlets, meat balls and so on enriching them with valuable mineral and protein components. The proposed technology for processing meat and bone raw materials allows obtaining meat and bone paste with the high proportion of mineral substances, in particular, calcium, magnesium, iron satisfying the daily requirement up to $50 \%$. The obtained meat and bone paste is recommended to use as a food additive in production of combined meat products.

Meat product manufacture using meat and bone paste ensures an increase in the product yield, broadens an assortment of manufactured products, contributes to an improvement of the ecological state of production and enables the rational use of secondary raw materials, thereby increasing economic efficiency. Moreover, this will give a noticeable economic effect with an increase in profitability of a product in the market [22]. With that, it is necessary to note that the ecological problem is solved simultaneously as all raw materials including those of low value are 
subjected to processing. Therefore, the proportion of industrial waste generated in case of consumption of poultry meat as carcasses or meat and bone semi-finished products is significantly reduced.

The above mentioned suggests the topicality of the development of the theoretical foundations and practice for deep non-waste processing of meat and bone raw materials and their use in new technologies for functional meat products to enrich them with valuable macro- and microelements and food nutrients.

The aim of the work was to study the chemical and mineral composition of the meat and bone paste from poultry and cattle bone raw materials.

\section{Materials and methods}

The objects of the research were samples of frozen meat and bone paste from poultry and cattle bones. Bones with residues of poultry and cattle muscle tissue were used for grinding. Meat and bone raw materials were obtained from meat processing enterprises and large meat trading pavilions in Semey city (Eastern Kazakhstan region, Kazakhstan Republic).

\section{Production of meat and bone paste for investigations}

At the first stage of the experiment, the scheme for meat and bone raw material processing was developed, which consisted in successive grinding of meat and bone raw materials preliminarily frozen to a temperature of $-18^{\circ} \mathrm{C} . .-$ $20^{\circ} \mathrm{C}$ in freezers. For the experiment on grinding of meat and bone raw materials, chicken bone products (chicken necks, drumsticks, wings, breasts) and cattle costal and vertebral bones with residues of muscle tissue were used for investigation.

Cattle costal and vertebral bones were preliminarily ground to a size of $50-70 \mathrm{~mm}$. Then, meat and bone raw materials were preliminarily frozen in freezers at a temperature of $-18{ }^{\circ} \mathrm{C} \ldots-20^{\circ} \mathrm{C}$ for $60 \mathrm{~min}$. After that, frozen raw materials were fed into a bin of a grinder with a diameter of plate holes of $8 \mathrm{~mm}$. After grinding, the obtained meat and bone mass was frozen to a temperature of $-18{ }^{\circ} \mathrm{C} \ldots-20^{\circ} \mathrm{C}$ and was ground again in a grinder with a diameter of plate holes of $5 \mathrm{~mm}$. Ice water was added to the meat and bone mass with the raw materials: water ratio of 1:0.5 and was mixed until obtaining a homogeneous mass $[23,24]$.

Then, meat and bone forcemeat was successively ground using a Supermasscolloider ultra-fine grinder with the following clearance between the nonporous grinders: $0.25 \mathrm{~mm}, 0.1 \mathrm{~mm}, 0.02 \mathrm{~mm}$. Meat and bone paste with tender spreadable consistency without a sense of toughness on the tongue was obtained at the exit of the grinder. The obtained meat and bone paste was stored at a temperature of $2-4{ }^{\circ} \mathrm{C}$ until the further experiments.

Determination of the total chemical composition was carried out by the method of a single weighed portion of the test sample. The method consisted in the successive determination of moisture ${ }^{1}$, protein ${ }^{2}$ and fat $^{3}$ in a single weighed portion.

Minerals were determined according to the normative documents R 4.1.1672-034 "Guidelines for quality control and safety of biologically active food additives", GOST 26928-86 "Foodstuffs. Method for determination of iron", GOST 33824-2016 "Foodstuffs and food ingredients. Stripping voltammetric method for determination of toxic elements (cadmium, lead, copper and zinc)".

Toxic safety was studied by the standard methods according to TR CU021/2011 Technical Regulations of the Customs Union "On the safety of food". Heavy metals $(\mathrm{Pb}$, As, $\mathrm{Cd}, \mathrm{Hg}$ ) were determined according to the normative documents: GOST 30178-968 "Raw material and foodstuffs. Atomic absorption method for determination of toxic elements", GOST R 51766-20019 "Raw material and food-stuffs. Atomic absorption method for determination of arsenic", MUC 4.1.1472-03 "Atomic absorption determination of the mass concentration of mercury in biomaterials of animal and plant origin (food, feed, etc.)".

Statistical analysis was carried out using the software package Statistica 6.0 and Excel 2007.

\section{Results and discussion}

At the first stage, the chemical composition of the meat and bone paste from poultry and cattle raw materials was studied. The bone tissue consists of the cellular elements and intercellular substance, which includes intermediate substance, formed particles - collagen fibers and inorganic salts [25]. The results of the chemical composition are presented in Table 1 . The results of the comparative analysis of the chemical composition show that the poultry and cattle meat and bone paste is characterized by the high protein content $(18.3 \%$ and $12.1 \%$,

${ }^{1}$ GOST 33319-2015. "Meat and meat products. Method for determination of moisture content". Moscow: Standartinform, 2018. - 14 p. (In Russian)

${ }^{2}$ GOST 25011-2017 "Meat and meat products. Protein determination methods". Moscow: Standartinform, 2018. - 14 p. (In Russian)

${ }^{3}$ GOST 23042-2015 "Meat and meat products. Methods of fat determination". Moscow: Standartinform, 2019. - 8 p. (In Russian)

${ }^{4} \mathrm{R}$ 4.1.1672-03 "Guidelines for quality control and safety of biologically active food additives". Retrieved from https://www.rospotrebnadzor. ru/upload/iblock/33e/r-4.1.1678_03.pdf Accessed December 11, 2020. (In Russian)

${ }^{5}$ GOST 26928-86 "Food-stuffs. Method for determination of iron". Moscow: Standartinform, 2010. - 6 p. (In Russian)

${ }^{6}$ GOST 33824-2016 "Foodstuffs and food ingredients. Stripping voltammetric method for determination of toxic elements (cadmium, lead, copper and zink)". Moscow: Standartinform, 2016. - 23 p. (In Russian)

${ }^{7}$ TR CU021/2011 Technical Regulations of the Customs Union "On the safety of food". Retrieved from http://docs.cntd.ru/document/902320560 Accessed December 11, 2020. (In Russian)

${ }^{8}$ GOST 30178-96 "Raw material and food-stuffs. Atomic absorption method for determination of toxic elements". Moscow: Standartinform, 2010. - 20 p. (In Russian)

${ }^{9}$ GOST R 51766-2001 "Raw material and food-stuffs. Atomic absorption method for determination of arsenic". Moscow: Standartinform, 2011. 12 p. (In Russian)

${ }^{10}$ MUC 4.1.1472-03 "Atomic absorption determination of the mass concentration of mercury in biomaterials of animal and plant origin (food, feed, etc.)". Retrieved from http://docs.cntd.ru/document/1200034851 Accessed December 11, 2020. (In Russian) 
respectively). This suggests the expediency of using meat and bone paste in products aimed towards compensation of deficiency in the human protein ration. This allows regarding meat and bone paste as a valuable raw material for food manufacture. The main protein of bone tissue is collagen [26]. Bone tissue collagen is assigned to fibrillar collagens of type I. Collagen is an important component in the composition of food products with a favorable effect on the state of beneficial microflora. A distinctive feature of collagen is the high content of proline and oxyproline. Moreover, collagen facilitates an increase in the emulsifying capacity of the system [27].

Significant differences in the fat content are seen. For example, the poultry meat and bone paste contains $11.8 \%$ of fat, which is higher than that in the cattle meat and bone paste (5.3\%). Bone fat is concentrated mainly in bone marrow. The peculiar characteristic of bone fat is the high content of lecithin compared to other types of animal fats. The high content of lecithin determines the good emulsifying capacity of this fat type and predetermines its use in production of emulsions [28].

The ash part of the meat and bone paste from poultry was equal to $4.35 \%$, from cattle $-6.80 \%$. Bones have very high stiffness and resilience, which is achieved by a peculiar combination of the organic base with minerals. Bone tissue is a source of mineral salts. It contains $98 \%$ of all inorganic substances in the body including $99 \% \mathrm{Ca}, 87 \% \mathrm{P}$, $58 \% \mathrm{Mg}, 46 \% \mathrm{Na}$ [29].

The chemical composition of bones is variable and depends on an animal breed, age and fatness, as well as on a bone type: the fat and mineral content is increased and water content is decreased with an increase in fatness [30].

The results of the mineral composition of poultry and cattle meat and bone paste are shown in Table 2.
Calcium is one of the most important elements for the human body ensuring its normal vital activities. Calcium improves the blood coagulability and nervous system function [35]. The human body cannot produce calcium by itself. Therefore, to maintain the sufficient level of calcium, it is necessary to intake it from different food sources [36]. The best method for meeting the need for this mineral is balanced nutrition with consumption of foods rich in calcium. However, food additives can also be a calcium source.

Analysis of the mineral composition of the meat and bone paste from poultry and cattle bones indicates the considerable calcium content. For example, the calcium content was $1,654.02 \mathrm{mg} / 100 \mathrm{~g}$ in the meat and bone paste from poultry bone raw materials and 5,318.13 mg/100g in the meat and bone paste from cattle bones. The significant difference in the calcium content is explained by the structure of cattle and poultry bone tissue. It is known that chicken bones are less hard and thinner than those of mammals; tubular bones do not contain bone marrow and are filled with air [37].

The comparative analysis of the mineral composition of the meat and bone paste and by-products from cattle (liver $-5.00 \mathrm{mg} / 100 \mathrm{~g}$, heart $-8.00 \mathrm{mg} / 100 \mathrm{~g}$, kidney $-13.00 \mathrm{mg} / 100 \mathrm{~g}$, tongue $-6.39 \mathrm{mg} / 100 \mathrm{~g}$, brain $43.00 \mathrm{mg} / 100 \mathrm{~g}$ ) and poultry (chicken liver $-15 \mathrm{mg} / 100 \mathrm{~g}$ ) revealed a significant excess of the calcium content in the meat and bone paste, excluding eggshell.

Another important macro-element for the human body is magnesium. Magnesium normalizes metabolic processes and prevents the development of allergy [38]. The magnesium content was $14.54 \mathrm{mg} / 100 \mathrm{~g}$ in the meat and bone paste from poultry bones and $207.62 \mathrm{mg} / 100 \mathrm{~g}$ in the meat and bone paste from cattle bones. The increased magne-

Table 1. Chemical composition of meat and bone paste from poultry and cattle bone raw materials

\begin{tabular}{|l|c|c|c|c|}
\hline Type of meat and bone paste & Moisture, $\%$ & Protein, $\%$ & Fat, $\%$ & Ash, \% \\
\hline Poultry meat and bone paste & $65.55 \pm 1.41$ & $18.3 \pm 0.36$ & $11.8 \pm 0.28$ & $4.35 \pm 0.12$ \\
\hline Cattle meat and bone paste & $75.8 \pm 1.91$ & $12.1 \pm 0.21$ & $5.3 \pm 0.17$ & $6.80 \pm 0.19$
\end{tabular}

Table 2. Mineral composition of poultry and cattle meat and bone paste compared to the mineral composition of by-products

\begin{tabular}{|c|c|c|c|c|}
\hline \multicolumn{5}{|c|}{ Minerals, mg/100g } \\
\hline Type of meat and bone paste & Calcium & Magnesium & Iron & Zinc \\
\hline Poultry meat and bone paste & $1,654.02 \pm 330.80$ & $14.54 \pm 2.91$ & $3.83 \pm 0.77$ & $0.070 \pm 0.020$ \\
\hline Cattle meat and bone paste & $5,318.13 \pm 1063.63$ & $207.62 \pm 41.52$ & $8.35 \pm 1.67$ & Not detected \\
\hline \multicolumn{5}{|c|}{ Cattle by-products (literature data) [31, 32] } \\
\hline Liver & $5.00 \pm 0.67$ & $18.00 \pm 2.90$ & $4.80 \pm 1.35$ & $4.00 \pm 2.85$ \\
\hline Heart & $8.00 \pm 1.67$ & $20.00 \pm 1.67$ & $4.30 \pm 0.08$ & $1.70 \pm 0.12$ \\
\hline Kidney & $13.00 \pm 0.22$ & $17.00 \pm 0.37$ & $4.60 \pm 0.18$ & $1.95 \pm 0.10$ \\
\hline Tongue & $6.39 \pm 1.07$ & $16.00 \pm 1.33$ & $2.15 \pm 0.33$ & $2.32 \pm 0.12$ \\
\hline Brain & $43.00 \pm 22.50$ & $13.00 \pm 0.00$ & $2.55 \pm 0.43$ & $1.02 \pm 0.20$ \\
\hline
\end{tabular}

Poultry by-products and eggshell (literature data)

\begin{tabular}{|l|c|c|c|c|}
\hline Chicken liver [33] & 15 & 24 & 17.5 & 6.6 \\
\hline Eggshell [34] & $33400-37300$ & $406-412.9$ & $2.8-41.3$ & $0.40-0.67$ \\
\hline
\end{tabular}


sium content in cattle bones is explained by its important role in balance maintenance and retention of calcium and phosphorous in bone tissue. Compared to other by-products, the magnesium content in the meat and bone paste from cattle bones is much higher than that in cattle and poultry by-products. Only eggshell contains more magnesium (406-412.9 mg/100 g).

Besides calcium and phosphorous compounds, bone tissue contains iron, copper and zinc. Iron in bone tissue facilitates calcification of bones of the skeleton. In addition, it is necessary for the cytochrome oxidase activity, which plays an important role in the bone cell function [39]. The high metabolic role of zinc is conditioned by the fact that it is an activator of several enzymes including alkaline phosphatase of bone tissue and others. An excess in calcium and copper inhibits zinc metabolism, processes of growth and differentiation of bone tissue, especially in tubular bones [40].

As for microelements, the iron content was the highest in the cattle meat and bone paste $(8.35 \mathrm{mg} / 100 \mathrm{~g})$; it was two times lower in the poultry meat and bone paste $(3.83 \mathrm{mg} / 100 \mathrm{~g})$ upon the reference daily intake of 1-2 mg. Among by-products, chicken liver was characterized by significant amounts of iron ( $17.5 \mathrm{mg} / 100 \mathrm{~g})$ compared to cattle liver $(4.80 \mathrm{mg} / 100 \mathrm{~g})$. Significant differences were observed in the zinc content. For example, the highest zinc content was recorded in the chicken liver $(6.6 \mathrm{mg} / 100 \mathrm{~g})$ and cattle liver $(4.00 \mathrm{mg} / 100 \mathrm{~g})$. Lower amounts of zinc $(0.070 \mathrm{mg} / 100 \mathrm{~g})$ were observed in the poultry meat and bone paste.

At the next stage, toxic safety of the meat and bone paste was determined (Table 3). The content and level of accumulation of heavy metals in the animal body depend on the kind of consumed feed and type of feeding, zone of raising, climatic conditions and so on. Heavy and toxic metals entering the animal body are accumulated mostly in bones, liver and kidneys.

As lead is widely distributed in nature in relatively high amounts, it is accumulated in the animal body, mainly in bones (90\%), comparatively quickly. Lead negatively affects the hematopoietic, nervous, digestive systems and kidneys [41].

Cadmium has high toxicity. Exposure to cadmium causes the oxidative stress in the animal body disturbing the oxidative and antioxidative balance [42]. Excessive accumulation of cadmium in the human body leads to the impaired renal function, dizziness, nausea, skin disorders, reduced appetite, increased arterial pressure, changes and pain in bones and joints.

Table 3. Content of toxic elements in meat and bone paste
The presence of arsenic compounds in foods results in serious human diseases later on. Long-term exposure to arsenic can lead to cancer development and skin lesions [43].

The other dangerous element is mercury. Mercury is toxic for the central and peripheral nervous system (mercurial erethism). Chronic poisoning causes predisposition to tuberculosis, atherosclerotic events, liver and gall bladder disorders, hypertension [44].

The critical levels of heavy metals were not revealed in the meat and bone paste: the lead content was $0.071 \mathrm{mg} / \mathrm{kg}$ and $0.056 \mathrm{mg} / \mathrm{kg}$, the arsenic content was $0.016 \mathrm{mg} / \mathrm{kg}$ and $0.011 \mathrm{mg} / \mathrm{kg}$. It corresponded to the norms of MACs by the content of toxic elements.

Therefore, animal and poultry bones are a rich source of mineral substances. The use of mineral constituents in the food technology upon proper technological and mechanical processing allows enriching products with mineral additives, in particular, calcium, magnesium and other elements.

\section{Conclusion}

As a result of the performed experiments, complex processing of meat and bone raw materials was proposed for production of meat and bone paste. The proposed technology for production of meat and bone paste from poultry and cattle bone products differs from existing ones due to the complex scheme of meat and bone processing including stepwise grinding with freezing and following processing to produce finely dispersed meat and bone paste suitable for the use with food purposes as food additives. Analysis of the chemical composition of meat and bone paste shows that meat and bone paste from poultry and cattle bones is a source of protein (18.3\% and $12.1 \%$, respectively), fat and minerals, which indicates its nutritional value. Analysis of the mineral composition revealed that the main constituent of the meat and bone paste was calcium, which content was $1,654.02 \mathrm{mg} / 100 \mathrm{~g}$ in the poultry meat and bone paste and $5,318.13 \mathrm{mg} / 100 \mathrm{~g}$ in the meat and bone paste from cattle bones. In regard to the toxic element content, critical levels of lead $(0.071 \mathrm{mg} / \mathrm{kg})$ and arsenic $(0.016 \mathrm{mg} / \mathrm{kg})$ were not revealed in the poultry and cattle meat and bone paste. The content of toxic elements in the meat and bone paste corresponds to food safety standards. The produced meat and bone paste from poultry and cattle meat and bone raw materials is a valuable source of minerals. Production of combined meat products with addition of meat and bone paste into a recipe allows improving the nutritional value of final products.

\begin{tabular}{|l|c|c|c|}
\multicolumn{1}{c}{$\begin{array}{c}\text { Toxic elements mg/kg, } \\
\text { not more: }\end{array}$} & $\begin{array}{c}\text { Norms according to normative } \\
\text { documentation }\end{array}$ & Poultry meat and bone paste & Cattle meat and bone paste \\
\hline Lead & 0.5 & 0.071 & 0.056 \\
\hline Arsenic & 0.1 & 0.016 & 0.011 \\
\hline Cadmium & 0.05 & Not detected & Not detected \\
\hline Mercury & 0.03 & Not detected & Not detected \\
\hline
\end{tabular}




\section{REFERENCES}

1. Kabulov, B., Kassymov, S., Moldabayeva, Z., Rebezov, M. Zinina, O., Chernyshenko, Y. at al. (2020). Developing the formulation and method of production of meat frankfurters with protein supplement from meat byproducts. EurAsian Journal of BioSciences, 14(1), 213-218.

2. Belousova, N.I., Manuylova, T.A. (2007). Complex use of raw material at the enterprises of meat industry. Food Industry, 7 , 38-41. (In Russian)

3. Cerceau Alves, Y. P., Fernandes Antunes, F. A., Silverio da Silva, S., Forte, M. B. S. (2021). From by- to bioproducts: Selection of a nanofiltration membrane for biotechnological xylitol purification and process optimization. Food and Bioproducts Processing, 125, 79-90. https://doi.org/10.1016/j.fbp.2020.10.005 4. Bhaskar, N., Modi, V.K., Govindaraju, K., Radha, C., Lalitha, R.G. (2007). Utilization of meat industry by products: Protein hydrolysate from sheep visceral mass. Bioresource Technology, 98(2), 388-394. https://doi.org/10.1016/j.biortech.2005.12.017

5. Kakimov, A.K., Yessimbekov, Z. S., Kabulov, B.B., Ibragimov, N.K., Suychinov, A.K. (2016). Effect of technological factors on meat-bone paste quality. Agro-Industrial Complex of Russia, 23(2), 466-472. (In Russian)

6. Toldrá, F., Mora, L., Reig, M. (2016). New insights into meat by-product utilization. Meat Science, 120, 54-59. https://doi. org/10.1016/j.meatsci.2016.04.021

7. Wei, Y., Xiaoyu, C., Wenhua, C., Zhijia, S. (2009). Status of Deep Processing Technology and Application of Animal Bone. Journal of Meat Research, 11.

8. Xiu-Fang, X. I. A. (2007). Comprehend utilization of livestock and poultry bones. Journal Meat Industry, 5, 013.

9. Wang, W., Zhang, Z. Y., Liu, D. Y., Zhang, J. M., Gou, X. H. (2009). New product development by processing and utilization of the animals' bone. Journal of Food Science and Technology, 34, 154-158.

10. Urazbaev, Zh, Z., Ualiev, S.N., Kakimov, A.K., Kabulov, B.B. (2010). Fundamentals of mechanical processing of raw materials of animal and vegetable origin and production technology of combined meat products. Semey: Shakarim University. - 259 p. (In Russian)

11. Antipova, L.V., Polyanskih, S.V., Orekhov, O.G., Sulina, Y.A. (2013). Substantiation applied aspects of bird bone balance rational using. Proceedings of the Voronezh State University of Engineering Technologies, 1, 109-114. https://doi. org/10.20914/2310-1202-2013-1-109-114 (In Russian)

12. Kutsakova, V.E., Kremenevskaya, M.I., Pogonyaeva, A. Yu., Kalmykova, T.S. (2013). Development of technology for hydrolysis of muscle tissue from the poultry meat and bone residue. Meat Industry, 4, 65-66. (In Russian)

13. Kutsakova, V.E., Moscvichev, A.S., Chemyshova, E.V., Elygina, K.A. (2006). About processing of wastes of poultry-processing industry. Journal of International Academy of Refrigeration, 3, 3638. (In Russian)

14. Neklyudov, A.D., Ivankin, A.N., Berdutina, A.V. (2000). Production and purification of protein hydrolysates (review). Applied Biochemistry and Microbiology, 36(4), 317-324. https://doi. org/10.1007/BF02738038

15. Mezenova, N. Yu., Agafonova, S.V., Mezenova, 0. Ya., Baidalinova, L.S., Volkov, V.V., Shenderyuk, V.I., Bedareva, O.M. (2020). The process of modifying cattle meat and bone raw materials by high-temperature hydrolysis. Processes and food production equipment, 1, 18-26. https://doi.org/10.17586/23101164-2020-10-1-18-26 (In Russian)

16. Wang, J.-Z., Dong, X.-B., Yue, J.-Y., Zhang, C.-H., Jia, W., Li, X. (2016). Preparation of Substrate for Flavorant from Chicken Bone Residue with Hot-Pressure Process. Journal of Food Science, 81(3), C578-C586. https://doi.org/10.1111/17503841.13211

17. Dong, X.-B., Li, X., Zhang, C.-H., Wang, J.-Z., Tang, C.-H., Sun, H.-M. at.al. (2014). Development of a novel method for hot-pressure extraction of protein from chicken bone and the effect of enzymatic hydrolysis on the extracts. Food Chemistry, 157, 339346. https://doi.org/10.1016/j.foodchem.2014.02.043

18. Zhang, G., Fan, A., Yue, X., Liu, G. (2010). Reutilization of waste chicken bone as nutrients source. 4th International Conference on Bioinformatics and Biomedical Engineering, iCBBE2010. Article 5517934. https://doi.org/10.1109/ICBBE.2010.5517934 19. Cansu, Ü., Boran, G. (2015). Optimization of a multi-step procedure for isolation of chicken bone collagen. Korean Journal for Food Science of Animal Resources, 35(4), 431-440 https://doi. org/10.5851/kosfa.2015.35.4.431
20. Suparno, O., Prasetyo, N.B. (2019). Isolation of collagen from chicken feet with hydro-extraction method and its physico-chemical characterization. IOP Conference Series: Earth and Environmental Science, 335(1), Article 012018. https://doi. org/10.1088/1755-1315/335/1/012018

21. Kodous, M. F.S.A. (2020).Physicochemical properties of hydrolyzed collagen produced from chicken feet. Middle East Journal of Agriculture Research, 9(1), 81-89. https://doi.org/10.36632/ mejar/2020.9.1.8

22. Kakimov, A., Suychinov, A., Yessimbekov, Z., Okuskhanova, E., Kuderinova, N., Bakiyeva, A., \& Mayorov, A. (2017). Meatbone paste as an ingredient for meat batter, effect on physicochemical properties and amino acid composition. Pakistan Journal of Nutrition, 16(10), 797-804. https://doi.org/10.3923/ pjn.2017.797.804

23. Kakimov, A.K., Kabulov, B.B., Yessimbekov, Z.S., Kuderinova, N.A. (2016). Use of meat-bone paste as a protein source in meat product production. Theory and practice of meat processing, 1(2), 42-50. https://doi.org/10.21323/2414438X-2016-1-2-42-50 (In Russian)

24. Kakimov, A., Kabdylzhar, B., Suychinov, A., Yessimbekov, Z., Baikadamova, A., Zolotov, A., Zharykbasova, K. (2019). The chemical profile and the effect of temperature and storage time on the change of yield stress and $\mathrm{pH}$ of meat-bone paste. EurAsian Journal of BioSciences, 13(2), 2093-2097.

25. Neklyudov, A. D. (2003). Nutritive fibers of animal origin: Collagen and its fractions as essential components of new and useful food products. Applied Biochemistry and Microbiology, № 39(3), 229-238. https://doi.org/10.1023/A:1023589624514

26. Kakimov, A.K., Kabdylzhar, B.K., Yessimbekov, Z.S., Gurinovich, G.V., Suychinov, A.K. (2020). Studying the chemical composition of chicken meat-bone paste. The Journal of Almaty Technological University, 127(2), 105-110. (In Russian)

27. Ismailova, D. Yu., Zinov'ev, S.V., Erokhina, O.N., Volik, V.G. (2015). Rational ways of processing collagen-containing raw materials in the poultry processing industry. Poultry and poultry products, 6, 55-57. (In Russian)

28. Orehov, 0.G. (2013). Justification obtain natural glue from the bone residue of broiler chickens. Proceedings of the Voronezh State University of Engineering Technologies, 3, 130-134. (In Russian)

29. Kakimov, A., Kabdylzhar, B., Yessimbekov, Z., Suychinov, A., Baikadamova, A. (2020). Identifying Patterns in the Effect Exerted by a Cooling Process and the Fine Grinding Modes on the Qualitative Indicators of a Meat and Bone Paste. Eastern-European Journal of Enterprise Technologies, 2(11-104), 6-12. https://doi. org/10.15587/1729-4061.2020.199554

30. Webster, J. D., Ledward, D. A., Lawrie, R. A. (1982). Protein hydrolysates from meat industry by-products. Meat Science, 7(2), 147-157. https://doi.org/10.1016/0309-1740(82)90080-8 31. Biel, W., Czerniawska-Piątkowska, E., Kowalczyk, A. (2019). Offal chemical composition from veal, beef, and lamb maintained in organic production systems. Animals, 9(8) https://doi. org/10.3390/ani9080489

32. Nasonova, V.V. (2018). Perspective ways the use of byproducts. Theory and practice of meat processing, 3(3), 6473. https://doi.org/10.21323/2414-438X2018-3-3-64-73 (In Russian)

33. Sidorova, K.A., Kozlova, S.V. (2015). Fundamentals of the formation of the nutritional value of chicken liver. Agro-food policy in Russia, 8(44), 70-72. (In Russian)

34. Rodionova N. S., Alekseeva, T. V., Kustov V. Yu., Popov E. S., Kalgina Yu.O. (2018). Aspects of obtaining forms of soluble organic calcium from the eggshell. Hygiene and sanitation, 97(8), 762-766. https://doi.org/10.18821/0016-9900-2018-97-8762-766 (In Russian)

35. Pravina, P., Sayaji, D., Avinash, M. (2013). Calcium and its role in human body. International Journal of Research in Pharmaceutical and Biomedical Science, 4(2),659-668.

36. Gromova, O.A., Torshin, I. Yu., Gogoleva, I.V., Grishina, T.R., Kerimkulova, N.V. (2012). Organic calcium salts: prospects for use in clinical practice. Russian Medical Journal, 20(28), 14071411. (In Russian)

37. Volik, V.G., Ismailova, D.Y., Zinowjew, S.V., Erokhina, O.N. (2017). Modern technologies of processing secondary raw materials of meat and piper processing industry. Rabbit breeding and animal husbandry, 3, 11-15. (In Russian)

38. Belluci, M.M., de Molon, R.S., Rossa, C., Tetradis, S., Giro, G., Cerri, P. at al. (2020). Severe magnesium deficiency compromis- 
es systemic bone mineral density and aggravates inflammatory bone resorption. Journal of Nutritional Biochemistry, 77, Article 108301. https://doi.org/10.1016/j.jnutbio.2019.108301

39. Spence, J. T. (2006). Challenges related to the composition of functional foods. Journal of Food Composition and Analysis, 19(SUPPL.), S4-S6. https://doi.org/10.1016/j.jfca.2005.11.007

40. Shlenkina, T.M., Lyubin, N.A., Stetsenko, I. I. (2013). Change of the content of microelements in the bone tissue of pigs under the influence of mineral additives. Vestnik of Ulyanovsk State Agricultural Academy, 2(22), 43-47. (In Russian)

41. Suganya, T., Senthilkumar, S., Deepa, K., Muralidharan, J., Sasikumar, P., Muthusamy, N. (2016). Metal toxicosis in poultry - a review. International Journal of Science, Environment and Technology, 5(2), 515-524.

42. Abd El-Hack, M.E., Alagawany, M., Arif, M., Chaudhry, M.T., Emam, M., Patra, A. (2017). Organic or inorganic zinc in poultry nutrition: A review. World's Poultry Science Journal, 73(4), 904915. https://doi.org/0.1017/S0043933917000769

43. Saha, J. C., Dikshit, A. K., Bandyopadhyay, M., Saha, K. C.(1999)

A review of arsenic poisoning and its effects on human health. Critical Reviews in Environmental Science and Technology, 29(3), 281-313. https://doi.org/10.1080/10643389991259227

44. Magos, L., Clarkson, T. W. (2006). Overview of the clinical toxicity of mercury. Annals of Clinical Biochemistry, 43(4), 257-268. https://doi.org/10.1258/000456306777695654

\section{AUTHOR INFORMATION}

Aitbek K. Kakimov - Doctor of Technical Sciences, Professor, Dean, Faculty of Further Education, Shakarim University of Semey. 071412, Republic of Kazakhstan, Semey, Glinka str.20A.Tel.: +7-777-242-57-92.E-mail: bibi.53@mail.ru

ORCID: https://orcid.org/0000-0002-9607-1684

Zhanibek S. Yessimbekov - PhD, Associate Professor, Department of technological equipment and mechanical engineering, Shakarim University of Semey. 071412, Republic of Kazakhstan, Semey, Glinka str. 20A. Tel.: +7-747-520-52-67. E-mail: ezhanibek@mail.ru ORCID: https://orcid.org/0000-0002-8556-9954

* corresponding author

Baktybala K. Kabdylzhar - Doctoral student, Department “Technology of food and processing industries", Shakarim University of Semey. 071412, Republic of Kazakhstan, Semey, Glinka str.20A. Tel.: +7-775-703-24-42. E-mail: baktybala.20@mail.ru ORCID: https://orcid.org/0000-0001-7935-0182

Anuarbek K. Suychinov - PhD, Director, Kazakh Research Institute of Processing and Food Industry (Semey Brunch). 071420, Republic of Kazakhstan, Semey, Baitursynova street, 29. Tel.: +7 70123318 14. E-mail: asuychinov@gmail.com

ORCID: https://orcid.org/0000-0003-4862-3293

Assemgul M. Baikadamova - Doctoral student, Department “Technology of food and processing industries”, Shakarim University of Semey. 071412, Republic of Kazakhstan, Semey, Glinka str.20A. Tel.: +7-775-175-69-67.E-mail: asemgul93@yandex.ru

ORCID: http://orcid.org/0000-0003-0062-6997

All authors bear responsibility for the work and presented data.

All authors made an equal contribution to the work.

The authors were equally involved in writing the manuscript and bear the equal responsibility for plagiarism.

The authors declare no conflict of interest.

Received 10.01.2021 Accepted in revised 15.03.2021 Accepted for publication 25.03.2021 